\title{
Gender awareness and the national machineries in the countries of Central and Eastern Europe
}

\author{
ZUZANA JEZERSKA
}

\section{Introduction: the basic problem of identification and terminology}

The countries of Central and Eastern Europe (CEE) saw fundamental changes to their political and social systems towards the end of the twentieth century. The processes of change affected most aspects of the social and political lives of the citizens of these countries. However, men and women experienced differently the burdens and gains of change. Furthermore, the processes of change took place in the context of globalization, which impacted upon the economic restructuring of CEE countries, as well as making demands upon their political structures to democratize. The state structure had to deal with these varied pressures. The Platform for Action of the United Nations' (UN's) Fourth World Conference on Women (Beijing, 1995) focuses on state structures for implementing gender mainstreaming (see Staudt, chapter 2 of this volume) under the chapter on national machineries for women. The chapter on national machineries seems to be often overlooked by both governmental bodies and the non-governmental organization (NGO) community in Central and Eastern Europe. There are several reasons for this: the domination of renewed traditional values in politics; transitional and at times unstable democratic/pluralist state structures; and the lack of active participation of women in political life.

Moreover, the definition of 'national machinery for the advancement of women' is very vague. It can vary from NGO status to a very strong mandate within the government. 
National machineries can be regarded as instruments for gender mainstreaming, as well as for the implementation of policies in other critical areas (see Kardam and Acuner, chapter 4 of this volume), though the UN Division for the Advancement of Women (DAW) consultation document (1998) cautions against burdening national machineries for women with taking on the role of implementation. Such definitional confusion is not a problem of this region exclusively, as other case studies in this volume indicate. This confusion is often reflected in the debates on women's national machineries. For example, should/can an institution, organization or ministry play the role of a national machinery for women only when it includes the word 'women' in its name? There are also issues regarding the discrepancy between form and content, proclaimed mandate and real contribution of the institutions deemed to represent women's interests at the national and global levels. Therefore, in the CEE region, we not only need gender awareness but awareness of the role and importance of national machineries for the advancement of women per se.

\section{Historical and political background}

The region of the CEE countries lived through perhaps one of the most controversial and differential processes of societal development in modern European history in the twentieth century. The First World War (1914-18) represented the culmination, and in fact the violent solution of a long period of political and social convulsion in the lives of the various social and ethnic groups inhabiting the region, especially those in the area of Central Europe. After the war, the Austro-Hungarian Empire disintegrated into new or newly shaped republics and states. Countries such as Czechoslovakia, Poland, Yugoslavia, Romania and even Austria and Hungary were re-created on the map of Europe. The free progress of new countries did not last too long. After the Second World War (1939-45), just about twenty years later, the strategic territory of Central Europe was again reshaped by the new superpowers. The Eastern part 
of it fell under the influence of the Soviet Union, except Yugoslavia and Albania, which achieved a measure of autonomy after breaking with Stalin's regime. The Soviet Union itself was the 'empire' of countries of very different cultural, societal and historical backgrounds.

The Soviet era brought about drastic changes to the history of Central and Eastern Europe. The political order and societal relations were authoritarian and not rooted in the historical experience of the region, thus resulting in dictatorships that mostly had little support within the populations. Socialist countries covered more than half of Europe and part of Central Asia in geographical terms. It is obvious, indeed, that the social, economic and cultural differences between these countries, though they were unified in the region by the power of collaborating Communist Parties, were significant. However, not all parts of this huge territory suffered in the same ways. The situation was much more complicated and is still waiting to be comprehensively analysed. In the period of political transformation starting in 1989, it emerged that substantial societal differences between individual countries persisted under the surface of uniform socialism and that serious problems among the countries had been suppressed and/or overlooked during the Soviet era.

\section{CEE countries and 'a policy for women'}

The unique territorial and historical features of the region presented particular gender dynamics for women. At the time of Soviet domination, the countries and their inhabitants were driven to adjust to the antithetical political and social structures not in a time frame of centuries, but of decades. Therefore, the social behaviour and societal consciousness of the population, which is in fact a matter of very slow evolution, developed controversial forms. Women as traditional carriers of responsibility for a basic social nucleus - the family - were perhaps the most affected by these socio-economic changes. Right after the Second World War, especially in the countries most wounded by the war 
(e.g. Russia, East Germany) women frequently replaced men in rebuilding post-war society. They often replaced men physically - working hard on the reconstruction of buildings and infrastructure - and they have been respected partners in the villages as well. However, as part of the Marxist understanding of gender relations, women's participation in the labour force as a means for women's emancipation came to be the basis of 'women's policy' in most of the region. This was a radical transformation of gender relations in most of the countries of the region, as it was only in a few countries, such as Czechoslovakia and Slovenia, that women made up more than 30 per cent of the work force before the Second World War. Later, when society was more stable, women in socialist countries gained some important advantages, especially in social fields such as the length of maternity leave, financial contribution during pregnancy and pre-school kindergarten. Health care was free of charge and progressive state provisions were also represented by other special treatments, for example preventive health examinations for women and children. The currently often-discussed abortion issue was a part of the health policy, but the state's policies on populations took precedence over women's rights (Davin, 1992; Siemienska, 1998). The official image of women changed rapidly from a pretty 'hausfrau' in the pre-war period to a worker and fighter for the socialist future together with men. Equality for all citizens (except those who were enemies of the regime) was enshrined in the Constitutions. Primary education was compulsory, illiteracy was disappearing and higher/university education was free of charge and open to everybody, especially those who were 'more equal' with the 'proper' (i.e. working class) family backgrounds. Women's level of higher education (with university and/or completed secondary education) ranked at 40 to 60 per cent in the region and rates concerning economic activity of women were also high as duty to work was also enshrined in the Constitutions. As far as societal consciousness was concerned, in most countries of the region, the persistence of traditionally rooted gender insensitivity framed by historical, religious and patriarchal order was confronted with the high educational and economic involvement of women. This, too, created a unique environment 
for most of the women in the countries of Central and Eastern Europe.

In a political sense, women were officially equal with men under the communist system. For example, 'the greatest number of women in the unicameral parliament [in Poland] under the Communist regime was 23 per cent, 1980-85', far higher than in many Western democracies (Siemienska, 1998:137). But it is difficult to speak about equality in a society where the ruling political party is the only ideological, economic and political power. Women were mostly organized in one association, frequently called the 'union of women', chaired by members of the Communist Party. While sometimes they were able to influence political decisions, decisions were not always made for the advancement of women and had to be in line with the Party. More often, 'women's associations just played a role of illusory state feminists' (Lokar, 2000).

\section{Governmental policy towards women after the fall of the 'Iron Curtain'}

The situation of women in the 1990s has been changing as fast as the 'new democracies' are transforming their economic and political systems. The similarities among countries of the region that were imposed by the logic of the state-centric system under the communist regimes are fast disappearing and specific indicators of the 'subregions within the region' are becoming more and more obvious. CEE countries are struggling with their problems individually, as well as in cooperation with other regional or global networks. European countries are now partners again - sometimes for good, sometimes for bad.

The governments of most CEE countries addressed issues concerning women in pre-Beijing Conference activities in close cooperation with the UN. There were exceptions, such as Poland, where the Government Plenipotentiary for Women was established in 1986 as a reaction to the World Conference to Review and Appraise the Achievements of the United Nations Decade for Women: Equality, Development 
and Peace, held in Nairobi in 1985. Not having been active participants in previous Conferences concerning women's issues, the UN Fourth World Conference on Women in Beijing represented the CEE countries' admission to dialogue and the policy process, which had started in 1975 at the global level. The Beijing Declaration and the Platform for Action stressed the need for continuing international cooperation with, and assistance to, countries with economies in transition. The Platform noted that 'In countries that are undergoing fundamental political, economic and social transformation, the skills of women, if better utilized, could constitute a major contribution to the economic life of their respective countries' (PfA: paragraph 159). Moreover, the regional activities of the Council of Europe focused on human rights issues; hence the issues concerning equality between women and men created a platform for starting discussion on the situation of women in the former socialist countries.

In the process of democratic reforms, the governments in the region formally recognized the importance of empowering both women and men to become partners in order to correct gender disparities inherited from the past and to promote gender equality. Nevertheless, having gained their independence a relatively short time ago, these countries have to find their individual way of economic transformation at the same time as they create new social structures. This process, contrary to the history of most Western European countries, is occurring under the pressures of time and political circumstances, which have consequences for the policy-making and implementational strategies and structures that are instituted. Furthermore, due to the diversity of countries in the region, now unencumbered by the artificial uniformity imposed by the power of the previous regime, and where the post-1989 changes have sometimes resulted in bitter civil wars, the enthusiastic anticipation of change has turned to complicated reality. And in this reality of conflicting priorities, the governments of the CEE countries do not have a very clear and classified policy for gender equality. Moreover, considerations of security and economic restructuring have been prioritized in policy-making processes, to the detriment of issues of equal opportunities and equal rights for women and men. 


\section{Global institutions and the gender agenda in CEE countries: relations with the UN}

The situation of women in the countries in transition was analysed at the UN regional seminar, 'Impact of Economic and Political Reform on the Status of Women in Eastern Europe', organized by DAW, which was held on 8-12 April 1991 in Vienna. The high-level Regional Preparatory Meeting of the Fourth World Conference on Women organized by the Economic Commission for Europe in Vienna, 17-21 October 1994, adopted the Regional Platform for Action. However, at that stage CEE countries were newcomers and were not experienced in women- and/or gender-related policy. A year after the Beijing Conference, on 12-14 September 1996, the regional Conference of Senior Governmental Experts was organized by the United Nations Development Programme's Regional Office in Bucharest. It focused on the 'Implementation of the Platform for Action Adopted by the 1995 Fourth World Conference on Women in Beijing, in Central and Eastern Europe'. As Angela King, then Director of DAW, emphasized in her opening statement, the Conference 'should [contribute] to increasing awareness among public policy makers, and to strengthening the institutional capacity of national machineries and other institutions in the region and activities of nongovernmental organizations, and the other actors of the civil society as well'. The Conference in Bucharest was of utmost importance, because it evaluated the progress made in the CEE countries and defined eleven priority objectives relevant to women's status in the region. These were:

- institutionalizing national machineries;

- facilitating equal participation of women in decision making;

- improving the economic and labour market situation of women;

- improving women's health, including reproductive health and family planning services;

- eliminating violence against women;

- reducing the effects of environmental degradation on women and improving women's role in environmental management; 
- reducing the social costs of transition;

- improving the situation of rural women;

- addressing the effects of armed conflicts on women, including the problems of displaced and refugee women;

- alleviating women's poverty, including the problems of minority groups of women, such as Roma women;

- utilizing the mass media for eliminating gender stereotypes and conducting gender training.

Discussion on national machineries emphasized the need to strengthen their institutional capacity, and urged the governments of the countries of the region to consider the following measures towards this goal:

- strengthening the mechanisms for the representation of women's issues within governmental structures and linking these mechanisms with the overall process of administrative reform;

- establishing national machineries at the highest level, such as the Office of the President or Prime Minister, in compliance with both the Economic Commission for Europe (ECE) and Beijing Platform for Action;

- developing inter-ministerial/interdepartmental cooperation with a view to achieving an integrated policy based on comparative gender analyses, as well as on evaluation of the effectiveness of such analyses for the purpose for determining the appropriate political, economic, social and legal frameworks for the improvement of women's living and working conditions;

- introducing the dimension of equality of opportunity as a permanent indicator in the analyses and evaluations of overall governmental activities;

- allotting material resources with a view to supporting, substantiating and distributing studies made in the field, and training experts and establishing institutions for studies and research in this area;

- addressing the need for consultative mechanisms aimed at fostering cooperation with parliamentarians;

- establishing coordination mechanisms among NGOs at the national level;

- supporting dialogue and bilateral and multilateral cooperation with all social partners.

Both the ECE Regional Preparatory Meeting in Vienna and the Beijing Conference thus gave an impetus to the 
development of the national machineries for the advancement of women in the CEE countries, and encouraged the governments to establish women's entities on different levels acting as national machineries for the advancement of women. Before the Beijing Conference only a few countries in the region realized the importance of establishing the institutional mechanisms for the advancement of women: they were Poland (1986), Russia (1993), Albania (1992) and Slovakia (1991). However, all of them had an unclear and limited mandate and were directly dependent on their host ministry. With the participation of the CEE governments in the UN-sponsored conferences and initiatives, there has been 'further development, in some countries, of existing institutional mechanisms for gender equality and creation of new ones; wider acceptance of the mainstreaming approach; growing awareness that gender equality and women's rights constitute a "common good" for humanity; awareness of the need for both traditional women's policies and gender mainstreaming policies' (UN/ECE, 1999a).

Since the Beijing Conference, some CEE countries have initiated some legislative reforms benefiting women and others have completed national plans for action, and/or have established national committees for women (or equality), and/or national ombuds person offices. Activities have also increased at local government level.

\section{Current situation of national machineries for the advancement of women in the CEE countries: case studies}

As has been mentioned previously, the environment of individual countries in the region differs quite a lot. Therefore, there is no common clue or model of and for the successful development and advancement of the national machinery in the region. Nevertheless, there are some positive examples and experiences as well as common obstacles and visions for future possible improvement.

A survey of the national machineries for women in the CEE countries reveals some important features of the processes affecting the establishment and functioning of 
national machineries for women (table 4). First, in the majority of CEE countries national machineries are located within the Ministry of Social Affairs and/or Labour. Often they have been set up by the order of a government or council of ministers (Albania, Bulgaria, Czech Republic, Hungary, Macedonia, Poland, Romania and Slovakia). In Russia and Ukraine, for example, they have been set up by presidential decree.

Second, in many countries the processes of economic and political transition have a direct bearing upon the life and functioning of the machineries. In some cases this takes the form of reconstituting and reconfiguring the name, size, membership and the site of the national machinery (see also Kwesiga, chapter 10 of this volume). So, for example, in Albania in 1992, the Women and Family Section was set up within the Ministry of Labour, Emigration and Social Affairs. Two years later it was upgraded to the Department of Women and Family and within the next two years it became the State Secretariat of Women attached to the Ministry of Culture, Youth and Women. In March 1997, the national machinery stepped backwards and was transferred to the Department for Women and Family in the same Ministry. In November 1997, it moved again to the Ministry of Labour and Social Affairs and in July 1998 by the decision of the Council of Ministers it was appointed the Committee on Women and Family, reporting directly to the Office of the Deputy Prime Minister (Katro-Beluli, personal interview, 1999). Finally, in March 2001 the name was changed to the Commission for Equal Opportunities.

Third, changes in government, in this period of transition, can have a disproportionate impact on the structures and powers of national machineries. In Poland, for example, there is no national machinery existing at present. In 1986, the Governmental Plenipotentiary for Women was created. It existed until 1991, when its name was changed to the Plenipotentiary for Women and Family. In 1995, it was renamed again as the Plenipotentiary for Family and Women. This functioned until October 1997, when the new right-wing government closed it down. In its place the Plenipotentiary for the Family was established in November 1997 (Lohmann, personal interview, 1999). Similarly, in Moldova we find that a governmental crisis in December 1999 
Table 4 National machinery in the CEE countries, June 2001

\begin{tabular}{|c|c|c|c|c|}
\hline Country & Name & $\begin{array}{l}\text { Year of } \\
\text { establishment }\end{array}$ & Host/location & Membership \\
\hline Albania & $\begin{array}{l}\text { Commission for Equal } \\
\text { Opportunities (named } 1 \\
\text { March 2001) }\end{array}$ & $\begin{array}{l}1992 \\
\text { (transformations } \\
\text { in 1994, 1996, } \\
1997 \text { and 1998) }\end{array}$ & Ministry of Labour & 8-9 employees \\
\hline Belarus & $\begin{array}{l}\text { The Family and Gender } \\
\text { Issues Department } \\
\text { National Council on Gender } \\
\text { Policy }\end{array}$ & 2000 & $\begin{array}{l}\text { Subdivision of the } \\
\text { Ministry of Social Welfare }\end{array}$ & $\begin{array}{l}\text { Representatives of Nationa } \\
\text { Assembly, Council of } \\
\text { Ministers, NGOs, scientist } \\
\text { and local authorities ( } 23 \\
\text { persons) }\end{array}$ \\
\hline Bulgaria & None at present & & & \\
\hline Croatia & $\begin{array}{l}\text { Committee for Gender } \\
\text { Equality (renamed in 2000) }\end{array}$ & 1996 & $\begin{array}{l}\text { Ministry of Labour and } \\
\text { Social Welfare }\end{array}$ & $\begin{array}{l}\text { One representative from } \\
\text { each ministry } \\
\text { (in Council } 5 \text { NGO } \\
\text { representatives) }\end{array}$ \\
\hline $\begin{array}{l}\text { Czech } \\
\text { Republic }\end{array}$ & $\begin{array}{l}\text { Division for Equality } \\
\text { between Men and Women }\end{array}$ & 1998 & $\begin{array}{l}\text { Ministry of Labour and } \\
\text { Social Affairs }\end{array}$ & 3 employees \\
\hline Estonia & Bureau of Equality & 1996 & Ministry of Social Affairs & \\
\hline
\end{tabular}


Table 4 (continued)

\begin{tabular}{|c|c|c|c|c|}
\hline Country & Name & $\begin{array}{l}\text { Year of } \\
\text { establishment }\end{array}$ & Host/location & Membership \\
\hline Hungary & $\begin{array}{l}\text { Secretariat for the } \\
\text { Representation of Women }\end{array}$ & 1996 & $\begin{array}{l}\text { Ministry of Family and } \\
\text { Social Affairs }\end{array}$ & \\
\hline Latvia & $\begin{array}{l}\text { Focal Point for the } \\
\text { Coordination of Gender } \\
\text { Equality Related Issues }\end{array}$ & 1999 & Ministry of Welfare & \\
\hline Lithuania & $\begin{array}{l}\text { Inter-ministerial } \\
\text { Commission for Equal } \\
\text { Opportunities for Women } \\
\text { and Men }\end{array}$ & & & \\
\hline Macedonia & Unit for Gender Equality & 1997 & $\begin{array}{l}\text { Ministry of Labour and } \\
\text { Social Policy }\end{array}$ & 1 person \\
\hline Moldova & $\begin{array}{l}\text { Department of Family Policy } \\
\text { and Equal Opportunities }\end{array}$ & & $\begin{array}{l}\text { Ministry of Labour, Social } \\
\text { Protection and Family }\end{array}$ & \\
\hline Poland & $\begin{array}{l}\text { None at present lonly } \\
\text { Plenipotentiary for the } \\
\text { Family) }\end{array}$ & & & \\
\hline Romania & $\begin{array}{l}\text { Direction for Equality of } \\
\text { Chances }\end{array}$ & 1995 & & \\
\hline
\end{tabular}


Interdepartmental

Commission for Equality

of Chances between

Women and Men

Russia

Commission for the

Advancement of Women

Government of Russian

Federation

Department for Equal

Opportunities

Slovenia

Office for Equal

Opportunities (renamed in 2001)

Ukraine Committee for Women's Affairs, Motherhood and Childhood

Sector for Women's Affairs, Family, Mother and Child Protection
Ministry of

Labour, Social

Affairs and

Family

1999

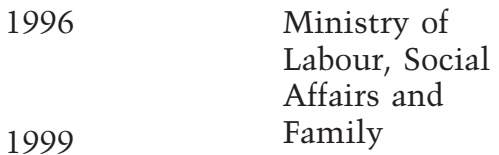

Government of the Republic of Slovenia

Ministry of Family and Youth

Attached to Cabinet of Ministers

\section{Deputy Head of State Government - Chair, members are appointed by the state government \\ Representatives of ministries, NGOs and experts \\ 2 employees}

Sources: UNDP RBEC/RSC, Bratistava, Slovakia, June 2001. National Machinery, Action Plans and Gender Mainstreaming in the Council of Europe. Regional Report on Institutional Mechanisms for the Advancement of Women in the Countries of Central and Eastern Europe, Warsaw: Karat Coalition Press, 2000. 
resulted in the abandoning of some strong structures of gender equality that included: the Equal Opportunities Subcommittee (within the Committee on Human Rights), established in 1998; the Committee on Women's Issues (February 1999), a consultative and coordinating body for the government; gender focal points within all ministries (starting in April 1999); and the Committee on Women and Family Issues (May 1999), instituted in order to assist the President of Moldova. The future of the national machinery is now unstable and unclear (Budrug-Lungu, personal interview, 2000).

Fourth, some of the CEE countries have experienced civil and ethnic conflict and war, and are yet to engage with issues of special structures for furthering women's position. Thus, 'Four years after the Dayton Peace Agreement where no one woman participated, Bosnia and Herzegovina is in a process of social, economic and political reconstruction as well as of establishing new legislative frameworks, but without giving any significant attention to issues of gender equality' (Helic, personal interview, 2000, League of Women in the Bosnia and Herzegovina Federation). This has been the experience of women in many countries where women's participation in political or military movements has not been reflected in the processes of institution building and where independent statehood has seen the marginalization of women in the political system (Jayawardena, 1989; Anthias and Yuval-Davis, 1990). Fifth, the processes and the dominant political discourses of transition also affect the shaping of national machineries. In the Czech Republic, for example, the government officially proclaimed the equality of all citizens and, therefore, excluded the existence of any further discrimination and other forms of inequality (Novakova, personal interview, 1999).

Sixth, the motivation to gain access to the European Union (EU), in the context of the Union's strong commitment to structures of gender equality, has been important to many transitional democracies in the CEE region. Thus the Czech Republic started the process of establishing the national machinery for the advancement of women at the beginning of 1998, in part motivated by the seriousness with which the EU regarded institutional mechanisms for the advancement of women. Wanting to be part of the EU 
was thus an important impetus for the establishment of the Czech national machinery (Simerska, personal interview, 2000).

Finally, while the external impetus to institute national machineries has been strong - both from the UN as well as the EU - in some countries the women's movements have had a considerable role to play in formation of national machineries. In Slovenia the Commission for Equality was the second to be established (in 1990) in CEE countries. It was the consequence of a genuine women's political movement separated from the communists. Starting in 1986, there is evidence of free and open political discussion on women in politics, and women and peace, violence, ecology and freedom of sexual orientation. In 1992, when the political orientation of the country shifted to the centre-left, the Governmental Office for Women's Policy was established. After the elections in 1996 women lost half of their representation in Parliament. Today, the Governmental Office for Women's Policy (renamed office for Equal Opportunities in February 2001) is very active in advocating for women's issues, but without a clear mandate and without real support from the Commission for Equality in Parliament, which is still formally in existence. These changes in the life cycle of national machineries due to political and economic pressures within the government and country point to the fragility of the machineries if they are not supported by strong women's movements from within civil society (Lokar, 2000).

Here one would also point to the trajectory of women's engagement with politics. Jaquette and Wolchik make the point that the politics of women's equality was associated with the ideological positions of the communist regimes and 'not with women's understanding of their own interests' (1998b:8). They also point out that in the CEE countries, women lacked experience in organizing in their own interests. Finally, they argue that international pressures, while helpful to evoke a state response, were not always supportive of gender politics: 'some of the most outspoken women in the region have complained of heavy-handed attempts on the part of Western feminists to pressure women in the region to conform to their views' (Jacquette and Wolchik, 1998b:91. 
There are thus many reasons for the rather patchy growth of women's national machineries. Some are political/ideological shifts in political discourses, as well as the pressures of governmental and party hierarchies on the one hand, and those of global and European institutions on the other. Other issues for the marginalization of women's machineries are to do with the lack of sustainability of governmental planning in many CEE countries, lack of mechanisms to hold governments to account and to monitor progress in the field, and 'in some parts of the region, insufficient understanding of the political significance of gender equality issues as issues of democracy and human rights' (UNIFEM, 1999|. However, what is lacking most is political will: the motivation of political leaders, both women and men, in decision-making positions to raise gender awareness, to disseminate information, to encourage gender-sensitive communication, and to insist upon mainstreaming gender issues in development strategies and policy planning.

\section{Looking ahead: national machineries in CEE countries in the twenty-first century}

Since December 1999, there has been significant progress in analysing, mapping and evaluating the situation of national machineries in the countries of Central and Eastern Europe. This is due to the increasing collaboration of national, regional and international networks at both official and NGO levels. The support of the international and/or European community, as well as the increasing strength of women's movements and groups within civil society, has also raised the awareness of governments in this regard. We have a saying in Slovakia: 'The road to hell is paved with good intentions.' Even an excellent idea is lost when it is not implemented well. In the current environment of the CEE countries, the following tasks of governmental structures should be given attention in order to build upon the recent advances made in mainstreaming gender in the policymaking and implementational structures of government. First, introducing and disseminating, to the widest possible population (not excluding official bodies), the idea of gender 
mainstreaming as an integral part of the progressive development of society as a whole. Second, understanding the importance of raising gender awareness at all social and territorial levels. Third, providing a gender approach in all forms of education and training. Fourth, stimulating and encouraging the mass media to produce and disseminate information on national and international activities in the field of gender issues. Fifth, constructing procedures for regular and open communication, within official bodies as well as from the bottom up and vice versa, in a sustainable manner. It is also important to formulate methodologies for monitoring processes of implementation of governmental policies on mainstreaming; to set up the indicators of progress made to date; to utilize feedback; and to set up other relevant controlling mechanisms. All this has to be done on a very transparent basis. Finally, the region of 'conflicting priorities' should not be isolated at any cost during the critical time of transformation. International, intergovernmental and regional institutions should be encouraged

to provide financial and technical assistance in support of institutional mechanisms and the development and implementation of tools for gender equality; and for countries in the region where financial support from donors is substantially decreasing, set up a technical assistance fund managed by an international or UN organization, where governments and NGOs could apply to obtain specialized technical expertise. (UNIFEM, 1999). 